WIDER Working Paper 2020/139

\title{
Migration and the labour market impacts of COVID-19
}

Nathan Barker, ${ }^{1}$ C. Austin Davis, ${ }^{2}$ Paula López-Peña, ${ }^{1}$ Harrison Mitchell, ${ }^{1}$ A. Mushfiq Mobarak, ${ }^{1}$ Karim Naguib, Maira Emy Reimão, ${ }^{3}$ Ashish Shenoy, ${ }^{4}$ and Corey Vernot ${ }^{1}$

October 2020 
Abstract: Using detailed microdata, we document how migration-dependent households are especially vulnerable during the COVID-19 pandemic. We create pre- and post-COVID panel datasets for three populations in Bangladesh and Nepal, leveraging experimental and observational variation in prior migration dependence. We report 25 per cent greater declines in earnings and fourfold greater prevalence of food insecurity among migrant households since March. Causes include lower migration rates, less remittance income per migrant, isolation in origin communities, and greater health risks. We compile a large set of secondary data to demonstrate the extent of vulnerability worldwide and conclude with recommendations for policy targeted at migrants.

Key words: migration, COVID-19, panel, Bangladesh, Nepal

JEL classification: O15, J61, I32

Acknowledgements: We are indebted to the study participants for generously giving their time. We are grateful to Mehrab Ali, Vibhuti Bhatt, Ashraful Haque, Alamgir Kabir, Rifaiyat Mahbub, Ashraf Mian, Shabib Raihan, Rubait Rahman, and Sneha Subramanian in Bangladesh and to Priyankar Chand and Arjun Kharel in Nepal for local research support.

The data collection and the research were funded by grants from the Bill and Melinda Gates Foundation, Evidence Action, Givewell.org, Global Innovation Fund, International Growth Centre, IZA (GLM-LIC programme), Mastercard Center for Inclusive Growth, UK Department for International Development, World Bank Group, UNU-WIDER, and Yale Research Initiative on Innovation and Scale. We thank, without implicating, participants at webinars organized by UNU-WIDER, World Bank DECRG Poverty Group, Inter-American Development Bank (COVID-19 and Labor Markets), World Bank Migration e-seminar, Universidad de San Andres, CERDI/Paris School of Economics seminar on Economics of Migration, the Bangladesh National Data Analytics Task Force, UNDP-Bangladesh, a2i-Ministry of Information and Communication Technology in Bangladesh, World Bank-Social Protection and Jobs-Africa Region, Innovations for Poverty Action, and BRAC for useful suggestions.

\footnotetext{
1 Yale University, New Haven, CT, USA; 2 American University, Washington, DC, USA; 3 Independent research scientist/consultant, Washington, DC, USA; ${ }^{4}$ University of Florida, Gainesville, FL, USA; 5 University of California, Davis, Davis, CA, USA; corresponding author: shenoy@ucdavis.edu

This study has been prepared within the UNU-WIDER project Transforming informal work and livelihoods.

Copyright (C) UNU-WIDER 2020

Information and requests: publications@wider.unu.edu

ISSN 1798-7237 ISBN 978-92-9256-896-2

https://doi.org/10.35188/UNU-WIDER/2020/896-2

Typescript prepared by Gary Smith.
}

United Nations University World Institute for Development Economics Research provides economic analysis and policy advice with the aim of promoting sustainable and equitable development. The Institute began operations in 1985 in Helsinki, Finland, as the first research and training centre of the United Nations University. Today it is a unique blend of think tank, research institute, and UN agency — providing a range of services from policy advice to governments as well as freely available original research.

The Institute is funded through income from an endowment fund with additional contributions to its work programme from Finland, Sweden, and the United Kingdom as well as earmarked contributions for specific projects from a variety of donors.

Katajanokanlaituri 6 B, 00160 Helsinki, Finland

The views expressed in this paper are those of the author(s), and do not necessarily reflect the views of the Institute or the United Nations University, nor the programme/project donors. 
COVID-19 is primarily transmitted through face-to-face contact, and migration therefore plays an outsized role in its global spread. Social distancing policies to contain the pandemic include limitations on geographic mobility within countries and hence differentially restrict employment for internal migrants. In addition, many nations have responded to the public health crisis by revoking work visas and evicting foreign workers. In this paper, we present evidence that both the public health risks of COVID-19 and the subsequent economic fallout have been particularly damaging to households that engage in labour migration, and propose policies to support them throughout the pandemic.

Households that rely on labour migration are uniquely vulnerable and merit policy focus because they make up a substantial share of the world's population. An estimated 272 million people live outside their country of birth, of which 192 million come from regions classified as 'less developed' (UNDESA 2019). International labour migration is a large component of the global economy; direct remittances to low- and middle-income countries (LMICs) in 2018 reached nearly US $\$ 500$ billion, triple the flow of official development assistance and roughly 80 per cent as much as foreign direct investment.

Internal migration is even more prevalent, with an estimated 763 million internal migrants worldwide, and is arguably more consequential for countries' development prospects. Two-thirds of all internal migration happens within LMICs, most originating in rural areas (UNDESA 2013). Poor households that engage in labour migration are a particularly vulnerable class because they face a triple threat: increased exposure to the virus, local economic exposure to the global downturn, and vulnerability to economic contraction in destination markets.

The economic conditions of labour migrants are also closely tied to broader public health aims as the disease spreads globally through travel. The International Labour Organisation (ILO 2020) estimates tens of millions of migrants have been stranded abroad without work during the pandemic and will seek passage home as travel restrictions abate. Finding economic solutions for these displaced workers must be a part of any comprehensive strategy for disease containment.

We conduct several household surveys to document how mobility is fundamental to economic livelihood worldwide. Low-asset households rely on frequent, short-term migration by individual members. Across a range of LMIC populations, we find migration episodes of under 12 months to be two orders of magnitude more common than in the USA. Moreover, the recent pace of urbanization in the developing world has created a large urban population with roots outside their city of residence. New urbanites move between markets and frequently travel to reunite with family in their place of origin. We further assemble the existing experimental evidence on the returns to temporary migration and find them to be large: migration raises household earnings by 50-250 per cent in Bangladesh, Kenya, Tonga, and Haiti. However, such mobility can be risky for public health during a pandemic.

To investigate the economic impacts of COVID-19, we construct panel data from phone interviews of representative samples of migrant and non-migrant households in April and May 2020 linked to prior field studies in Bangladesh and Nepal. The panel nature of our data allows us to credibly identify how COVID-19 differentially affects migrant households across a variety of important outcomes. Surveys include participants in a 2013 work visa lottery, among whom we have experimentally induced variation in the propensity to migrate, and rural populations with high rates of migration in northern Bangladesh and southwestern Nepal. We find declines in earnings during the COVID-19 period to be 25 per cent greater among migrant households than among non-migrant households across all samples. This leads to excess food insecurity up to four times greater than that faced by non-migrant households.

These impacts are potentially widespread in our countries of study. An estimated 200,000 Bangladeshis returned to the country earlier in 2020, before borders closed, and the International Organization for 
Migration (IOM) anticipates another wave of comparable magnitude once borders reopen (IOM 2020a). Similarly, the Government of Nepal is preparing to repatriate 400,000 displaced workers. In our own data from within Bangladesh, one-quarter of low-skill construction workers in major cities returned to their towns of origin between March 1 and June 15. The urban construction sector alone employs 8.8 per cent of working males (UNFPA 2016), indicating return migration by a substantial portion of the population.

We demonstrate how migrant employment influences household welfare primarily through loss of remittance income. This loss is driven by both lower rates of migration-existing migrants sent home and new migrants unable to depart-as well as decreased remittances from those who remain away. This implies that not only do displaced workers experience lower earnings currently (many having already incurred upfront travel costs), but their families will also remain vulnerable without future remittances. For households that rely on migration, declines in income can persist even after COVID-19 no longer poses a local threat.

Data show that these households do not make up for the loss through alternative local economic opportunities, leading them to be worse off than households that never migrated. Reintegration into the local economy is especially challenging during this crisis. Beyond the usual barriers (e.g., skill transferability, weaker social networks), COVID-19 introduces the additional burden of isolation as locals fear viral contagion from returnees. This isolation is difficult to overcome because the fear is justified: our syndromic surveillance data show that households with recent returnees—especially from abroad-are more likely to display WHO/CDC COVID-19 symptoms than households without returnees.

Migrants and their families are therefore uniquely exposed to both the public health and economic fallout from the COVID-19 pandemic, and should be a primary focus of support. Remittance income is necessary for meeting basic caloric needs for many households, and neglecting this fact, especially during the agricultural lean season and other regular times of economic distress, might create its own nutritional crisis. Moreover, in the absence of financial relief, the strong incentive to migrate-particularly for households already near subsistence-may hinder compliance with travel directives. If households feel they have no option but to send a migrant for income, they may make decisions that accelerate the spread and deepen the impacts of COVID-19 in origin and destination areas. Section 5 proposes shortand medium-term policy responses for this sector.

Our work complements the widely cited World Bank (2020a) forecast predicting a 19.9 per cent decline in global remittance income in 2020, with only a modest 5.2 per cent recovery in 2021 . This forecast is constructed by interacting projections of national income in host countries with historical remittance elasticities, but may be inaccurate if the relationship differs in the current climate due to unique features of the global pandemic. Deaton (2005) discusses similar shortcomings of national accounts data in measuring household welfare. By contrast, we deploy detailed household surveys to directly evaluate the relationship between COVID-19 and household remittance earnings. In the months immediately following the pandemic outbreak, we observe declines larger than forecasted.

We add to a growing body of literature that highlights how the impacts of COVID-19 reinforce existing socioeconomic disparities. On the public health side, low-income populations face greater rates of mortality due to limited healthcare access and pre-existing comorbidities (e.g., Barnett-Howell and Mobarak 2020; Garg et al. 2020). We document how the prevalence of short-term migration accelerates transmission among poor populations in developing countries, and how policies restricting movement can place additional pressure on the nutritional health of those living close to subsistence (see also Egger et al. 2020).

We illustrate how the link between earnings and mobility exacerbates the exposure of the poorest households to this particular crisis. This channel is unique to the nature of a global pandemic, which requires 
limitations on mobility to slow the spread. Our research expands on existing work that finds the greatest labour market impacts from COVID-19 among industries with high concentrations of migrant labour (Borjas and Cassidy 2020; Fasani and Mazza 2020; Garrote Sanchez et al. 2020; Gelatt 2020; Kerwin et al. 2020). Related research has shown a similar relationship between wealth and employment based on how well occupations can accommodate working from home (Dingel and Neiman 2020; Gottlieb et al. 2020; Saltiel 2020). We add to these findings by documenting how labour market shocks are transmitted into household welfare using high-quality microdata from developing countries.

In Section 2 we describe the various sources of data we draw upon. Section 3 describes the importance of labour migration prior to the outbreak. Section 4 presents our main findings on the heightened economic and medical impacts of COVID-19 on migrant households. We conclude in Section 5 by discussing potential policies targeted at migrant populations.

\section{Data and methodology}

We present new evidence on how COVID-19 and associated social distancing policies differentially affect households that do and do not rely on migration income. For this, we combine new phone survey data with existing household records among two samples in Bangladesh and one in Nepal. All three samples were selected based on participation in prior research on migration and seasonality by the authors of this paper, which allows us to control for pre-existing economic differences between households, and are statistically representative of their underlying populations. Data collection from each of these studies was either ongoing or complete by February 2020.

We re-contacted household participants from each sample by phone in April-May 2020 with questions about health symptoms, earnings and financial distress, recent movement, and social distancing measures. The three main study samples are summarized in Table 1, with further details in Appendix A1.

Bangladesh-Malaysia visa lottery: The Government-to-Government (G2G) visa lottery study consists of Bangladeshi individuals who applied for a work visa in Malaysia in 2013. Due to oversubscription, visas were awarded by lottery to 30,000 of the nearly 1.5 million applicants. A random sample of 3,512 households representing lottery winners and losers were contacted in August-December 2018 for in-person surveying, and we reached 2,937 of these by phone. Visas were allocated by lottery, so this sample provides experimental variation in the propensity to migrate, with visa lottery winners 58 percentage points more likely to have a household member migrate internationally in the subsequent five years. Details of the original study are discussed by Shrestha et al. (2020).

Nepal rural communities: The Nepal Seasonality (NPL) study consists of 1,820 households sampled from the bottom half of the wealth distribution in multiple wards of the Western Terai region of Nepal. We construct a household panel from six rounds of phone surveys between August 2019 and July 2020, and the final round included additional COVID-specific questions. Migration-dependent households in this sample are defined as those that reported remittances to be their primary source of earnings in 2019. Details of the original study are discussed by Mobarak and Vernot (2020).

Bangladesh landless agricultural workers: The No Lean Season (NLS) study experimentally evaluates a large-scale programme to offer seasonal migration loans to landless agricultural workers in northern Bangladesh. The project made loan offers to 19,000 households in 2018, and a random sample of 8,490 eligible households drawn from both offered and non-offered villages were surveyed in person in March and June 2019. We contacted a random sample of 294 households from this sampling frame by phone, stratified by both treatment and prior migration status. Migration dependence in this sample is defined as having a household member migrate temporarily in at least one of the previous three years. Details of the original study are discussed by Bryan et al. (2019). 


\begin{tabular}{|c|c|c|c|c|}
\hline Sample & Description & Identification & Original survey design & Outcome variables \\
\hline $\begin{array}{l}\text { G2G } \\
(2,937 \mathrm{HHs})\end{array}$ & $\begin{array}{l}\text { Bangladeshi participants } \\
\text { in a } 2013 \text { visa lottery for } \\
\text { work permits in Malaysia }\end{array}$ & $\begin{array}{l}\text { Randomized variation in propensity to mi- } \\
\text { grate induced by visa lottery in pre- and } \\
\text { post-COVID periods }\end{array}$ & $\begin{array}{l}\text { In-person surveys of } 3,512 \text { house- } \\
\text { holds in August-December } 2018 \\
\text { representing both lottery winners } \\
\text { and losers }\end{array}$ & $\begin{array}{l}\text { Income: monthly income from Spring } 2019 \\
\text { and April } 2020 \\
\text { Health: reported symptoms in April } 2020 \\
\text { Isolation: reports of social exclusion }\end{array}$ \\
\hline $\begin{array}{l}\text { NPL } \\
(1,419 \mathrm{HHs})\end{array}$ & $\begin{array}{l}\text { Households in bottom } \\
50 \text { th percentile of wealth } \\
\text { in rural parts of western } \\
\text { Terai, Nepal }\end{array}$ & $\begin{array}{l}\text { Diff-in-diff pre- and post-COVID between } \\
\text { households that do and do not report re- } \\
\text { mittance income as the primary source of } \\
\text { earnings in } 2019 \text {, with a long panel of pre- } \\
\text { periods to verify parallel trends }\end{array}$ & $\begin{array}{l}\text { Six rounds of phone surveys be- } \\
\text { tween August } 2019 \text { and July } 2020 \\
\text { with } 2,636 \text { rural households }\end{array}$ & $\begin{array}{l}\text { Income: labour earnings from October } 2019 \\
\text { and April } 2020 \\
\text { Food security: six months of } 2019 / 2020 \text { and } \\
\text { every month of prior year }\end{array}$ \\
\hline $\begin{array}{l}\text { NLS } \\
(294 \mathrm{HHs})\end{array}$ & $\begin{array}{l}\text { Landless agricultural } \\
\text { households in northern } \\
\text { Bangladesh eligible for } \\
\text { short-term migration loan }\end{array}$ & $\begin{array}{l}\text { Diff-in-diff pre- and post-COVID between } \\
\text { households with and without a member } \\
\text { away in } 2016-19 \text {, with a long panel of pre- } \\
\text { periods to verify parallel trends }\end{array}$ & $\begin{array}{l}\text { In-person surveys of } 4,324 \text { house- } \\
\text { holds in March and June } 2019\end{array}$ & $\begin{array}{l}\text { Food security: four months of } 2020 \text { and ev- } \\
\text { ery month of } 2018 / 2019 \\
\text { Health: reported symptoms in May } 2020\end{array}$ \\
\hline $\begin{array}{l}\text { CBPS } \\
(899 \mathrm{HHs})\end{array}$ & $\begin{array}{l}\text { Rohingya refugee camps } \\
\text { and host communities in } \\
\text { Cox's Bazar, Bangladesh }\end{array}$ & $\begin{array}{l}\text { Descriptive facts about about health and } \\
\text { isolation faced by households with and } \\
\text { without a migrant }\end{array}$ & $\begin{array}{l}\text { In-person surveys of 5,000 house- } \\
\text { holds July } 2019\end{array}$ & $\begin{array}{l}\text { Health: reported symptoms in April } 2020 \\
\text { Isolation: self-reported social participation }\end{array}$ \\
\hline $\begin{array}{l}\text { URB } \\
(1,093 \\
\text { workers })\end{array}$ & $\begin{array}{l}\text { Urban labourers at over } \\
200 \text { spot markets for day } \\
\text { labour, primarily in con- } \\
\text { struction, in nine cities in } \\
\text { Bangladesh }\end{array}$ & $\begin{array}{l}\text { Descriptive facts about transportation and } \\
\text { urban labour conditions prior to and during } \\
\text { COVID-19 }\end{array}$ & $\begin{array}{l}\text { In-person enumeration of } 19,396 \\
\text { workers in September } 2018 \text { and } \\
\text { follow-up phone survey with } 8,490 \\
\text { respondents in April } 2019\end{array}$ & $\begin{array}{l}\text { Return migration: prevalence of return mi- } \\
\text { gration by urban migrants in March-May } \\
2020\end{array}$ \\
\hline
\end{tabular}

Note: $\mathrm{HH}$, household.

Source: authors' construction. 
For each sample, we perform a household-level difference-in-differences regression of income and food security on dummy indicators for migration dependence and time. In the G2G sample, this regression is identified by experimental variation in the propensity to migrate from the visa lottery. Furthermore, in the NPL and NLS samples, we show that monthly rates of food insecurity are nearly identical in migrant and non-migrant households in 2018-19 and the first two months of 2020, providing strong evidence for the parallel trends assumption necessary for identification.

We provide further descriptive information using two other sets of surveys conducted by the authors. Information regarding the prevalence of COVID-19 symptoms and the isolation faced by non-migrant and migrant households comes from the Cox's Bazar Panel Survey (CBPS), a sample collected in July 2019 of 5,000 refugee and host households in the Cox's Bazar district of Bangladesh, with a random sample of 899 households reached by phone for a COVID-19 survey. Data on migration prevalence also encompasses a survey of 19,396 workers at 200 spot labour markets in nine Bangladeshi cities (URB) conducted in September 2018, and follow-up phone surveys of 8,490 of these workers in April 2019 and 1,093 in May 2020.

We supplement the primary data with a number of secondary sources to document the prominence of migration around the world. Sources include national surveys in Nepal, Uganda, and the USA-the few nationally representative surveys we found that document short-term migration of individual household members-as well as data generated by several other studies on the prevalence of and returns to labour migration. The full set of secondary data is described in Table 2 .

Table 2: Secondary data sources

\begin{tabular}{|c|c|c|c|}
\hline Function & Data source & Population & Sample \\
\hline \multirow{8}{*}{$\begin{array}{l}\text { Descriptive statistics on } \\
\text { national migration rates }\end{array}$} & (NLSS) Nepal Living & Nepal & 5,988 \\
\hline & Standards Survey & & \\
\hline & (UNPS) Uganda National & Uganda & 1,237 \\
\hline & Panel Survey & & \\
\hline & (SIPP) Survey of Income & United States & 237,711 \\
\hline & and & & \\
\hline & Program Participation & & \\
\hline & Morten (2019) & Rural India & 440 \\
\hline \multirow{5}{*}{$\begin{array}{l}\text { Descriptive statistics on } \\
\text { migration rates in specific } \\
\text { sub-populations }\end{array}$} & \multirow{2}{*}{ Banerjee et al. (2015) } & Ultrapoor in Lempiras, Honduras & 654 \\
\hline & & Ultrapoor in Cusco, Peru & 669 \\
\hline & Barker et al. (2020) & Rural Northern and Upper East Ghana & 2,975 \\
\hline & Baseler (2020) & Rural Western Kenya & 485 \\
\hline & Imbert and Papp (2020) & Rural poor in India & 2,224 \\
\hline \multirow{2}{*}{$\begin{array}{l}\text { Descriptive statistics on } \\
\text { migration rates during a peak } \\
\text { migration period }\end{array}$} & Banerjee et al. (2015) & Ultrapoor in Cusco, Peru & 669 \\
\hline & Imbert and Papp (2020) & Rural poor in India & 2,224 \\
\hline \multirow{5}{*}{$\begin{array}{l}\text { Estimates of the returns } \\
\text { to migration using randomized } \\
\text { variation }\end{array}$} & Akram et al. (2017) & Northern Bangladesh & 5,792 \\
\hline & Baseler (2020) & Western Kenya & 485 \\
\hline & McKenzie et al. (2010) & Tonga & 198 \\
\hline & Shrestha et al. (2020) & Bangladesh & 3,512 \\
\hline & $\begin{array}{l}\text { Clemens and Postel } \\
(2017)\end{array}$ & Haiti & 30 \\
\hline
\end{tabular}

Source: authors' construction. 


\subsection{Mobility during COVID-19}

Migrant populations warrant focus during this pandemic because they face heightened risk from both the direct impacts of the disease and the policy response. A number of studies document how migrantheavy sectors in OECD countries, such as transportation and hospitality, have experienced the largest contractions since the onset of the pandemic (Borjas and Cassidy 2020; Fasani and Mazza 2020; Garrote Sanchez et al. 2020; Gelatt 2020; Kerwin et al. 2020). Thus, migrant workers face diminished prospects for employment and income.

Further economic exposure stems from mobility restrictions that feature prominently in public health policy. To limit personal contact, nearly every country in the world has incorporated social distancing into its COVID-19 response. Measures include restrictions on gatherings, stay-at-home orders, and mandatory curfews. Importantly, most nations have adopted restrictions on domestic and international travel to slow the geographic diffusion of the illness. In a 26 March audit of 1,596 national border crossings, the IOM (2020b) recorded that 1,372 crossings had imposed limitations on mobility. By 17 April, 161 of 190 countries evaluated had instituted barriers to internal mobility as part of their pandemic response (IMF 2020). Early evidence indicates that such limitations have been successful in slowing the spread of the disease (Flaxman et al. 2020; Hsiang et al. 2020; Kraemer et al. 2020).

Barriers to mobility are prominent in social distancing efforts in our study areas of Bangladesh and Nepal. As of 16 May and 28 May, respectively, both countries had implemented a variety of measures, including curtailing public transport, barring non-essential travel, and limiting internal movement. Additionally, Bangladesh banned international arrivals from some regions while Nepal imposed a complete border closure (Hale et al. 2020). Table A1 in the Appendix describes mobility restrictions in these countries more thoroughly.

At the same time, these policy responses and the global economic downturn have spurred a mass return of migrant workers around the world. In India alone, between March and May an estimated 10 million domestic migrants returned home, and the Government of India brought back another 500,000 international migrants stranded abroad (GoI 2020; Roy and Agarwal 2020; Tribune 2020). An estimated 200,000 Bangladeshis returned to the country earlier in 2020, before borders closed, and the IOM in Bangladesh anticipates another wave of comparable magnitude once borders reopen. Similarly, the Government of Nepal is preparing to repatriate 400,000 displaced workers (IOM 2020a).

In our own URB data on internal migration among urban day-labourers in Bangladesh, one-quarter of low-skill construction workers in major cities returned to their towns of origin between 1 March and 15 June. The urban construction sector in Bangladesh employs 8.8 per cent of all working males (UNFPA 2016), meaning this loss of employment alone affects a substantial portion of the population. This mass return of urban labour is corroborated by the NLS data, in which 65 per cent of households report having a migrant return between 15 March and 15 May 2020, compared to just 10 per cent over the same period in 2018 and 2019.

\subsection{Prevalence of short-term migration}

Short-duration, high-frequency migration is a fundamental component of household earnings in LMICs, leaving their populations particularly vulnerable during this crisis. Panel A of Figure 1 plots the annual share of households that participate in temporary migration-lasting under 12 months - for several populations. The calculations draw from multiple sources, including both targeted research surveys and nationally representative samples collected by statistical offices, summarized in Table 2. Importantly, 
the data include detailed information on episodes of short-term and circular migration, as well as cases in which individual workers migrate while the household remains behind.

Figure 1: Role of labour migration in household earnings (a) Short-term migration rates

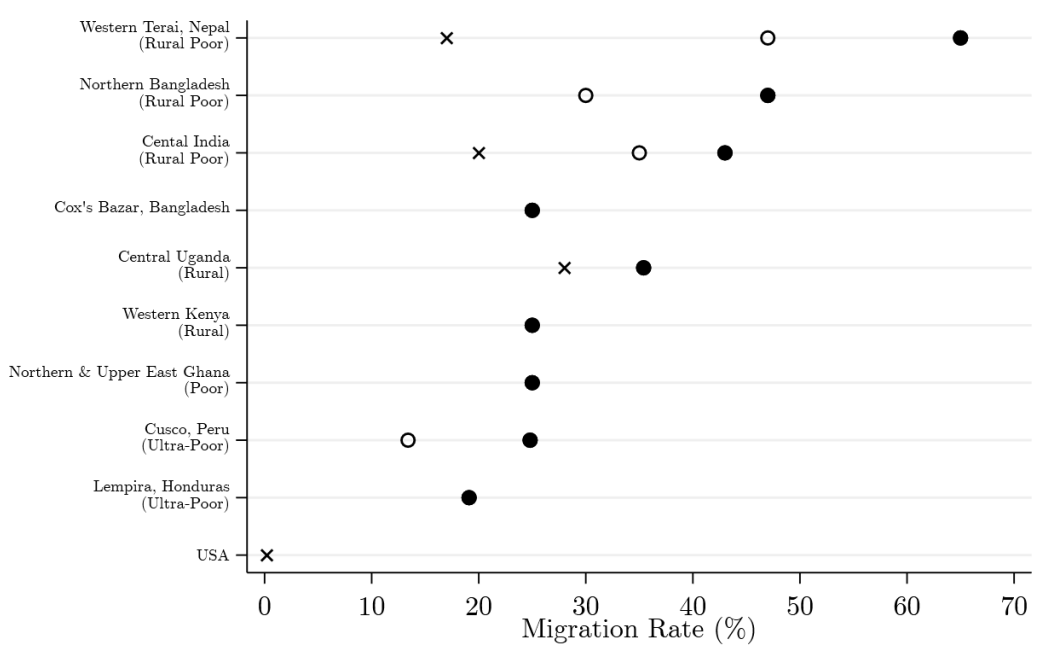

Sub-Population, Annual o Sub-Population, Peak Season $\times$ National Avg., Annual

(b) Experimentally estimated returns to migration

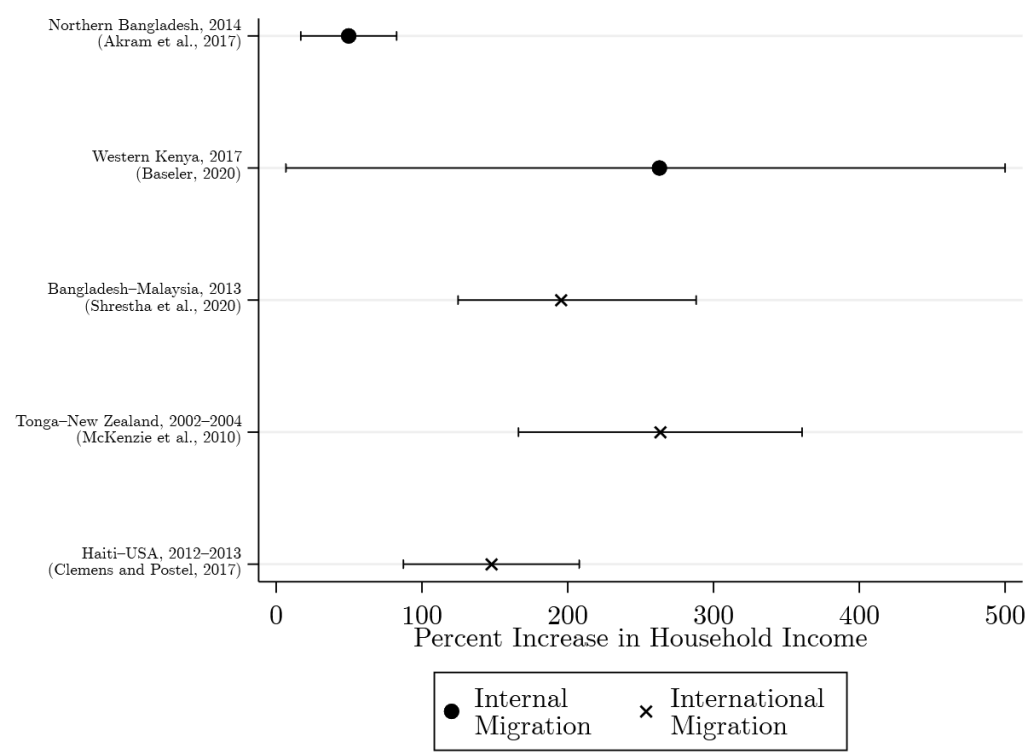

Note: (a) fraction of households with a departing migrant who returns in under 12 months. (b) Point estimates of the return to migration from studies using randomization or lotteries with 90 per cent confidence intervals $(\mathrm{Cl})$ as reported in the study. The 90 per cent $\mathrm{Cl}$ found in Baseler (2020) exceeds 500 per cent and is truncated for display purposes.

Source: authors' construction based on the data sources listed in Table 2.

Panel A illustrates three important features of short-term migration around the world. First, it is extremely common in the LMIC countries for which we have data. Among countries in Asia, Africa, and Latin America, between one-fifth and half of households have at least one member temporarily away for work. By contrast, the annual rate in the USA is below 0.2 per cent.

Second, within LMICs, short-term migration is concentrated among identifiable populations and regions. In particular, poorer and more rural populations engage in migration at elevated rates. In Nepal, India, and Uganda, where data on rates among the general population are available, we identify sub-populations 
for whom the rate of migration is up to four times higher than the national average. ${ }^{1}$ That is, specific locations and sectors are at even greater risk.

Third, short-term migration is frequently seasonal, especially among rural populations. The first three rows of Panel A report departure rates during the peak migration season in rural Nepal, northern Bangladesh, and Central India. ${ }^{2}$ Peak-season migration accounts for more than half of overall short-term migration in these populations. ${ }^{3}$ This fact suggests that, in addition to targeting specific populations, economic policy should be appropriately timed throughout the year.

Frequent mobility is a salient feature among parts of the urban labour force as well. The fraction of the population in LMICs living in urban areas has grown by 25 per cent over the last 20 years (World Bank $2020 b$ ), leading to a swell in urban workers with roots elsewhere. Recent urban arrivals frequently move between markets to find short-term wage work, and often travel to visit extended family. In our URB sample of urban labour markets, 85 per cent of workers identify a different subdistrict and 79 per cent a different district from the labour market in which they were interviewed as their native place. Six months later, more than half were located in a new market and 50 per cent reported travelling to visit their native home at least once in September-December 2018. These are the most vulnerable urban workers, rotating across markets to find day-labour without a steady or guaranteed source of income.

\subsection{Mobility and household earnings}

Migrant income is a meaningful contributor to household earnings across our samples in contexts where it is prevalent. Among G2G lottery winners, remittances comprised 33 per cent of household income in 2018 for the family remaining in Bangladesh, and 63 per cent when the visa holder was still abroad.

In the NLS sample, migrant earnings accounted for 18 per cent of total earnings over a seven-month period from October 2018 to May 2019, concentrated during times of low rural earnings capacity. Among NPL households, remittances brought home by returnees during the October-November 2019 rice harvest made up 60 per cent of household labour income in those months, despite it being a time of high agricultural productivity. Remittances are integral to many households' economic calculus, so an unanticipated drop in remittance income is detrimental.

Experimental evidence indicates that the relationship between migration and earnings is causal, and the economic returns to migration are substantial. ${ }^{4}$ The first two rows of Panel B in Figure 1 report results from two randomized evaluations of internal migration programmes in developing countries. The first row describes a pilot of the NLS programme. Estimates of the local average treatment effect (LATE) on those who migrate upon receiving a migration loan indicate that migration boosts household earnings by 50 per cent over the following six months (Akram et al. 2017). This benefit is directly observed in food consumption, with migrant households consuming 750 more calories per person per day during the agricultural lean season (Bryan et al. 2014). The second row of Panel B reports results from a Kenyan experiment providing information about urban wages to rural households. Baseler (2020) estimates an

\footnotetext{
${ }^{1}$ By contrast, in the USA the rate of short-term migration is not substantially greater than the national average for any education category or any specific non-military industry or occupation.

2 Data from the other sources do not include information on departure timing.

${ }^{3}$ By comparison, in the USA there is no single month where departures exceed 10 per cent of the annual rate; migration is distributed evenly throughout the year.

${ }^{4}$ There is a large literature on non-experimental estimates of the return to migration that we omit for space. See Lagakos et al. (2020) for a summary.
} 
even larger LATE of a 263 per cent increase in earnings among households with members experimentally induced to migrate by the information shock.

Evidence from randomized allocations of work visas points to similarly high returns to international migration. The remaining three rows of Panel B report results from studies of international work visas allocated by lottery. Shrestha et al. (2020) evaluate a visa lottery in Bangladesh for work in Malaysia and find that household income doubles for households able to send a migrant due to winning the lottery. McKenzie et al. (2010) compare winners and losers of a Tongan visa lottery for migration to New Zealand and estimate the LATE returns to migration to be 263 per cent of household earnings. In a visa lottery for Haitians to work for 2-3 months in the US agricultural sector, Clemens and Postel (2017) estimate average yearly income for households able to send a migrant increases by 148 per cent after working for only a few months away. The returns to these migration episodes, of both short and medium duration, demonstrate that migration income is not easily replicated locally.

\section{$4 \quad$ Results}

Economic contraction and barriers to mobility due to COVID-19 have been disruptive worldwide, but we observe disproportionately large declines in earnings and food security among migrant households. These declines are driven primarily by loss of remittance earnings, caused by both lower rates of migration and less remittance income from the remaining migrants. We present suggestive evidence that return migrants face difficulty integrating into local labour markets. Our findings reveal a unique channel of exposure to the global downturn: although migrant populations face an elevated risk of infection, even households and regions with little health risk can be adversely affected if they are linked to impacted areas by labour migration.

\subsection{Effects on income and food security}

Across all three survey samples, we consistently find that the COVID-19 economic shock has hit migrant households especially hard. We first investigate this question using experimental variation from the lottery outcome for participants in the G2G visa lottery. Monthly income fell 36 per cent from spring 2019 to April 2020 overall in this sample. Panel A of Figure 2 shows that lottery winners, who are 58 per cent more likely to have a migrant household member than lottery losers, enjoyed higher earnings on average prior to COVID-19 but have experienced a 25 per cent greater decline in earnings $(p<0.05)$ since the onset of the pandemic. The frequency of reporting no earnings from any source in April is nearly twice as high $(p<0.01)$ among lottery winners $(10.2$ per cent $)$ than lottery losers $(5.4$ per cent $)$, compared to a rate of 1.3 per cent among both groups in 2019. Results are robust to including household fixed effects and to using 2018 as the base year.

A nearly identical pattern appears in the NPL sample, shown in Panel B. Comparing labour income from the April 2020 wheat harvest to the October 2019 rice harvest, households that reported remittances as their primary source of income in 2019 have higher earnings at baseline but experience a 25 per cent greater drop during the pandemic. Even these numbers may understate the full economic loss. In western Terai, remittances typically peak when migrants return home and bring money back by hand. Thus, we would expect to see a surge in remittances around the onset of the pandemic as migrants return uncharacteristically early. Future remittance income may fall even further below its typical level as barriers to mobility shift migration returns forward in time, with workers unable to travel back to their host markets. 
Figure 2: Impact of COVID-19 crises by migrant-sending status

(a) G2G income

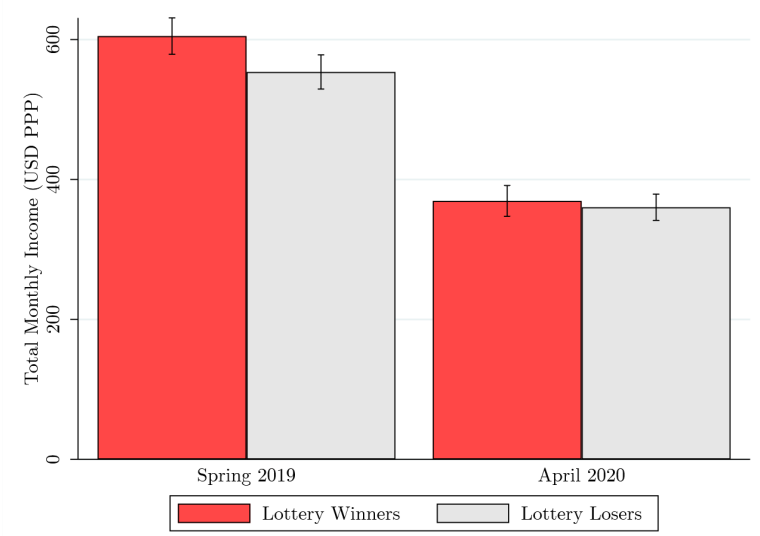

(c) NLS food insecurity

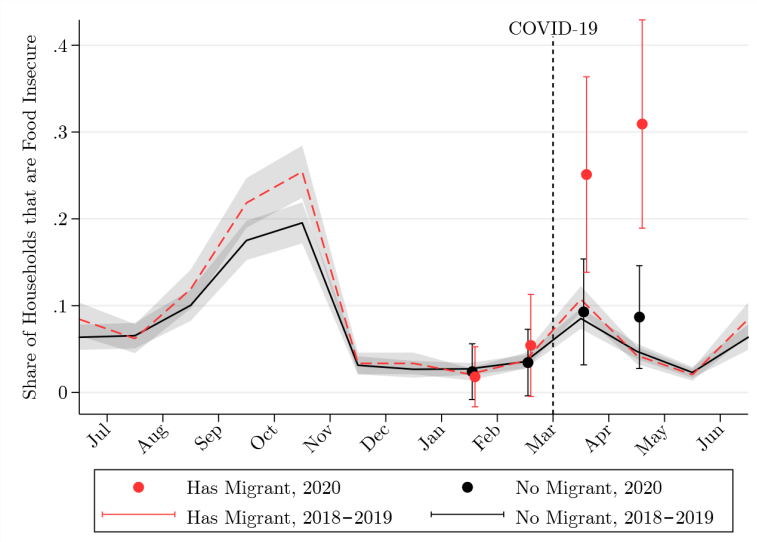

(b) NPL income

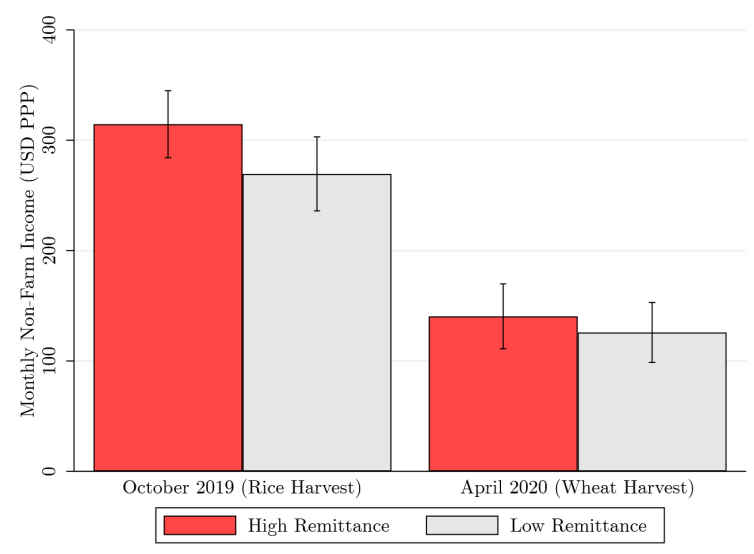

(d) NPL food insecurity

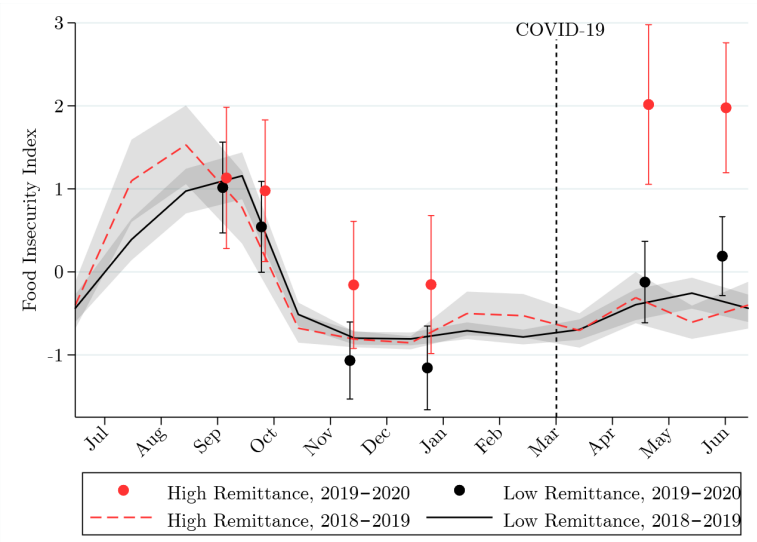

Note: means and 95 per cent CI. (a) G2G income is monthly earnings from wages, business, remittances, capital, non-governmental organizations, friends and family, and home production. (b) NPL income is the sum of earnings from wages and remittances. High Remittance indicates households that listed remittances as their primary source of income in 2019. (c) NLS food insecurity is the fraction of households that restricted the number or size of meals for more than half the month; "has migrant' indicates households that had at least one temporary migrant in 2016-19. (d) NPL food insecurity is a standardized index of two questions in 2019 and 2020.

Source: authors' construction based on the sources listed in Table 1.

We next show evidence that these declines in earnings translate into heightened food insecurity for migrant households. This measure, which tends to be more stable over time as households smooth consumption, verifies that the observed shocks represent real economic distress rather than temporal displacement of income that households can insure.

In the NLS sample, a substantial gap in food security appears between migrant and non-migrant households after the outbreak of COVID-19. We plot the fraction of households reporting restricted food intake for more than half the month in Panel C, split by presence of a migrant in the previous three years. Prior to 2020, with data spanning January 2018 to June 2019, rates of food insecurity are nearly identical between households with and without migrants. The largest gap of 4-6 percentage points appears during the September-October lean season. Food insecurity in 2020 follows this pattern in January and February, but spikes among migrant households in March and April. Food insecurity among migrant households in April 2020 exceeds 30 per cent, surpassing the typical lean season peak of 25 per cent, while increases among non-migrant households are much more modest. We reject that the current migrant-non-migrant difference is equal to prior years $(p<0.01)$, to January and February 2020 $(p<0.01)$, and to the prior lean season peak $(p<0.05)$. 
Similar disparities appear in the NPL sample. Panel D of Figure 2 compares an index of food insecurity in late 2019 and early 2020 to prior years in the NPL sample. The gap between high- and low-remittance households exceeds two standard deviations, and the rate of food insecurity among migrants resembles a typical lean season. We reject that the current migrant-non-migrant difference is comparable to prior years $(p<0.01)$, to the October 2019 harvest $(p<0.01)$, to the November-December 2019 post-harvest $(p<0.05)$, and to the prior lean season peak $(p<0.05)$.

\subsection{Lost income and remittances}

Where we have data on earnings by source, we document substantial declines in remittance earnings consistent with heightened vulnerability for migrant populations. Panel A of Figure 3 shows the change in earnings by source in the G2G sample from April 2018 to April 2020. ${ }^{5}$ Among visa lottery winners, remittances account for 83 per cent of lost income, and lost remittances alone equal the total decrease in earnings among lottery losers. Even among lottery losers, remittance income makes up 39 per cent of the earnings decline as a substantial fraction relied on alternative migration channels prior to the pandemic.

Figure 3: Decline in remittance earnings

(a) G2G earnings declines by type

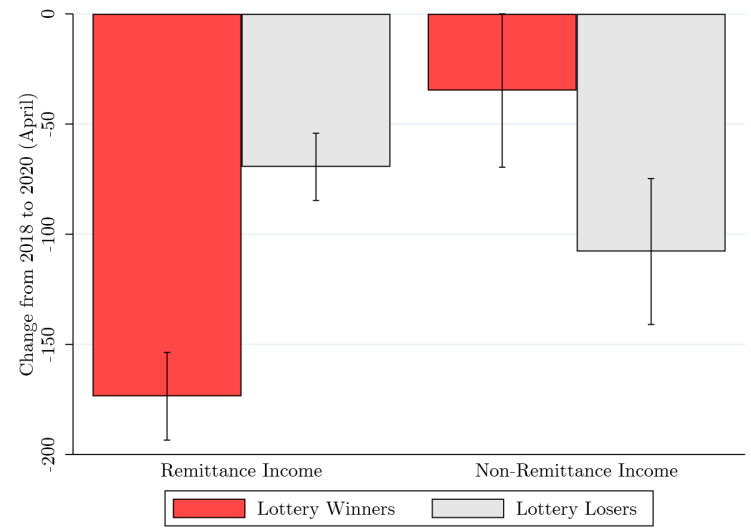

(c) NPL fraction of households with adult male away

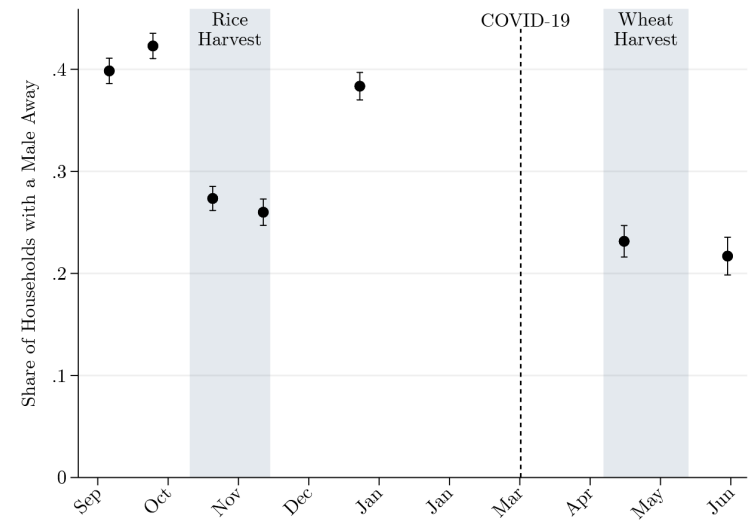

(b) NPL remittance earnings by month

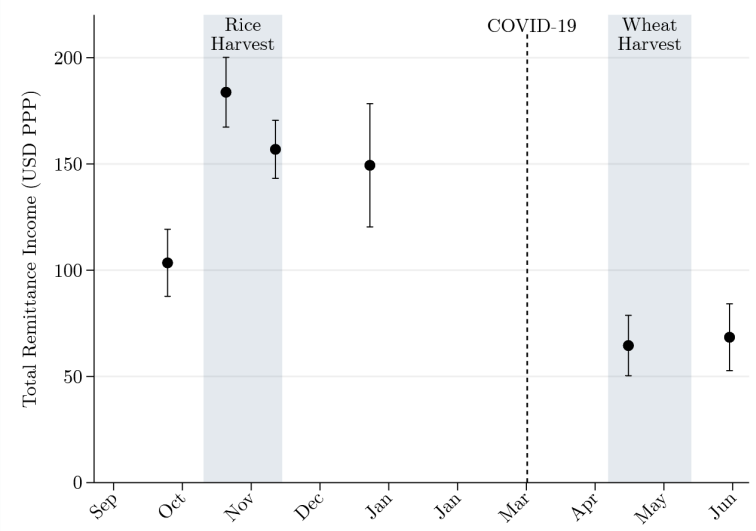

(d) NPL remittances per adult male away

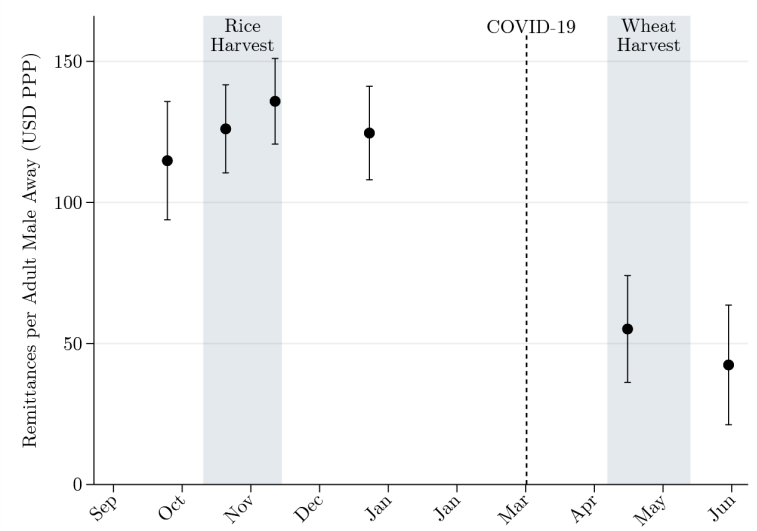

Note: means and 95 per cent Cl. (a) G2G changes in household income from April 2018 to April 2020 by source. (b) NPL remittance income by month. (c) NPL fraction of households with an adult male away by month. (d) NPL remittance earnings per adult male away by month.

Source: authors' construction based on the sources listed in Table 1.

\footnotetext{
${ }^{5}$ We do not have granular data for April 2019.
} 
The role of remittances is even more stark in the NPL sample, where the majority of the population relies on external income. Remittance earnings in April 2020 (during the wheat harvest) are 65 per cent lower than during the 2019 rice harvest, shown in Panel B. Remittances typically peak in harvest periods as men returning for agricultural work bring back foreign earnings by hand. Remittance earnings account for 74 per cent of the decline in labour income among households who identify remittances as their primary source of income and for 67 per cent of the decline among households who identify a different primary source.

This decrease is caused by declines in both the rate of migration and migrant earnings. Panels C and D break remittances down into their component pieces. Only 23 per cent of households had a male ${ }^{6}$ migrant away during the 2020 wheat harvest, below the typical annual nadir of 26 per cent during the autumn rice harvest. This fraction has subsequently fallen even further rather than climbing post-harvest, unlike the prior season. Moreover, even migrants who remain abroad during the pandemic earn far less than normal. Monthly earnings per migrant have fallen by 56 per cent from US $\$ 126$ PPP (purchasing power parity) in autumn 2019 to US\$55 PPP in April and May 2020. These differences are statistically significant $(p<0.01)$ and robust to controlling for household fixed effects.

\subsection{Migrant health and isolation}

The observed income and consumption shocks indicate that households are unable to recover lost migration income in local labour markets. We find evidence of lower market participation among return migrants in the NPL sample. Hours devoted to wage labour have declined across the entire sample, but the decrease is twice as large for those who travelled in the previous six months after controlling for household and worker characteristics. There is some substitution towards home enterprises, but this alternative makes up for less than 50 per cent of the gap. The previous results on income and food security verify that households with migrant workers face larger economic losses during the pandemic.

In addition to typical barriers to reintegration, such as skill transferability and loss of social networks, COVID-19 presents a further complication in the isolation of returnees. Anecdotes abound of communities being hostile to and even barring entry for returning migrants for fear for their own health and safety (e.g., Agarwal 2020; Janetsky 2020). An April 2020 survey of 558 migrants returning to Bangladesh in January-March (BRAC 2020) finds 29 per cent of returnees felt their neighbours and relatives were unsupportive and unwelcoming.

We observe direct reports of isolation in the G2G sample, in which households are four times more likely to report exclusion from social events (relative to a base of 3 per cent) and three times more likely to report exclusion from prayers (from a base of 6 per cent) due to fears of COVID-19 if they have a returning migrant in the previous two weeks. Indirect responses corroborate diminished community participation. Visa lottery winners were 25 per cent ( 9 percentage points) less likely to attend Friday prayer services than lottery losers. This difference is not driven by religiosity as rates of prayer are equal across the two groups; the discrepancy only arises at the typical community gathering time. Without preCOVID data, we cannot determine whether this isolation is typical for returning migrants or unique to the current pandemic. In either case, it hinders reintegration at a time when migrants are vulnerable.

The exclusion of returning migrants may be driven in part by increased infection risk. We administered syndromic surveillance of WHO/CDC symptoms, and use the existence of three common COVID-19 symptoms - fever, dry cough, and fatigue - as a proxy for COVID risk. We then relate symptom frequency to the presence of a recently returned migrant in the household or community. In both the G2G and CBPS samples, where international migration is prevalent, we observe a correlation between returning migrants and COVID-19 symptoms. The likelihood of self-reporting a COVID-19 symptom doubles

\footnotetext{
${ }^{6}$ Labour migrants in this region are overwhelmingly male.
} 
(from 7 per cent to 14 per cent in the G2G sample and from 16 per cent to 33 per cent in the CBPS sample) where an international migrant has returned in the previous two weeks. In the NLS sample, where migrants typically remain in the country, the rate of self-reported COVID-19 symptoms is 20 per cent greater in households with a recent returnee.

Labour migrants face particularly high risks of exposure in transportation and housing. Among those in the NLS sample who migrated in 2019, over 95 per cent travelled on a high-density vehicle such as bus or train. At the destination, almost three-quarters lived at the work site or other employer-provided housing; 95 per cent shared sleeping quarters with at least three other individuals, and 40 per cent slept in rooms with 10 or more workers.

Migration also appears to induce exclusion from medical care. Thirty-seven per cent of households in the CBPS sample that had a member temporarily away in the previous two weeks report that patients with COVID-19 symptoms are not permitted to receive medical care, compared to 28 per cent among households whose members did not travel.

Our survey findings corroborate conclusions from two recent studies that use administrative data to establish a link between migration and the spread of COVID-19 at the subnational level. Ahsan et al. (2020) and Valsecchi (2020) show that regions of Bangladesh and Italy connected to COVID-19 hotspots through migration subsequently faced more severe local contagion.

\section{Discussion}

We demonstrate how the centrality of migration leaves households uniquely vulnerable to both the COVID-19 public health crisis and economic downturn. Our results are important because mobility is a fundamental aspect of earnings in much of the developing world, and COVID-19 itself is transmitted along migration channels.

Social distancing without accompanying financial relief risks lowering nutritional intake below subsistence levels, which can permanently damage productivity and child development. Moreover, financial pressure may undermine containment efforts as households with few alternatives seek employment where they can find it, even possibly in violation of health guidelines. Therefore, successful health policy must directly address migrant wellbeing.

While many countries have issued general stimuli in response to COVID-19, it is often inadequate for those most affected. For instance, the Government of Bangladesh announced transfers of BDT2,000 (US\$24) to an estimated four million impacted families. While the stimulus represents over 3 per cent of the country's GDP, the planned transfers are small relative to foregone migration income. Scaled against experimental results, the government support compensates at most one month of foregone migration earnings.

The inadequacy of this relief can already be seen in political backlash. In April, there were 147 protests spanning 43 of 64 districts in Bangladesh calling for greater economic support. Outside the major cities of Dhaka and Chittagong, protests were most common in districts with high rates of seasonal labour out-migration, such as Rangpur, Nilphamari, and Gaibandha (Saydia 2020). As shutdowns persist and extend into the peak migration season, pressure from vulnerable populations will only increase.

Based on our findings, we advocate detailed policy analysis to identify migrant-sending communities and appropriately target medical and economic resources. Analysis should include both sub-populations and times of year with heightened vulnerability, recognizing that economic and medical exposure may 
not necessarily coincide. Immediate relief efforts should then direct financial support in the form of cash or food aid to migration-dependent households that have lost remittance income.

Beyond immediate stabilization, foregone income can be offset through local reintegration or eventual repatriation. Reintegration cannot be a complete solution because migrants earn more away than they would at home even during normal economic times. As a temporary measure, reintegration is challenging because of the health risks associated with mobility. Policy makers can facilitate it by making testing available and engaging in public messaging to safely reduce migrant exclusion and ensure the safety of workers and their communities.

Over the longer term, economic policy should prioritize safe return to destination markets when appropriate. As contagion stabilizes, reopening requires balancing trade-offs between economic necessity and public health risk, and the value of employment should be included in this calculus. Sectors high in migrant labour provide an irreplaceable source of income to otherwise vulnerable households.

Policy can further facilitate the safe return to work. Domestically, this means enforcing workplace safety standards as well as providing transportation and housing options that allow for adequate social distancing. For international migrants, nations should track entry requirements at destinations, and create facilities for testing and quarantining to satisfy these requirements. The faster such infrastructure is in place, the sooner migrant-dependent households can recover their past standards of living.

\section{References}

Agarwal, P. (2020). 'Bihar's Migrants Return to Face Stigma, Under-Prepared Medical Facilities'. IndiaSpend, 1 April.

Ahsan, R., K. Iqbal, M. Khan, A.M. Mobarak, and A. Shonchoy (2020). 'Using Migration Patterns to Predict COVID-19 Risk Exposure in Developing Countries'. Yale Research Initiative on Innovation \& Scale Policy Brief. New Haven, CT: Yale University.

Akram, A.A., S. Chowdhury, and A.M. Mobarak (2017). 'Effects of Emigration on Rural Labor Markets'. NBER Working Paper 23929. Cambridge, MA: NBER. https://doi.org/10.3386/w23929

Banerjee, A., E. Duflo, N. Goldber, D. Karlan, R. Osei, W. Parienté, J. Shapiro, B. Thuysbaert, and C. Udry (2015). 'A Multifaceted Program Causes Lasting Progress for the Very Poor: Evidence from Six Countries'. Science, 348(6236). https://doi.org/10.1126/science.1260799

Barker, N., G. Bryan, D. Karlan, A. Ofori-Atta, and C. Udry (2020). 'Escaping Poverty: Comparing Livelihood Approaches for the Ultra-Poor in Ghana'. AEA Randomized Controlled Trial. Registry ID AEARCTR0003638

Barnett-Howell, Z., and A.M. Mobarak (2020). 'Should Low-Income Countries Impose the Same Social Distancing Guidelines as Europe and North America to Halt the Spread of COVID-19?'. Yale Research Initiative on Research \& Scale. New Haven, CT: Yale University.

Baseler, T. (2020). 'Hidden Income and the Perceived Returns to Migration: Experimental Evidence from Kenya'. Mimeo. https://doi.org/10.2139/ssrn.3534715

Borjas, G.J., and H. Cassidy (2020). 'The Adverse Effect of the COVID-19 Labor Market Shock on Immigrant Employment'. NBER Working Paper 27243. Cambridge, MA: NBER. https://doi.org/10.3386/w27243

BRAC (2020). 'The Impact of COVID-19 Pandemic on the Life and Livelihoods of Returnee Migrants'. Technical Report. Dhaka: BRAC.

Bryan, G., S. Chowdhury, and A.M. Mobarak (2014). 'Underinvestment in a Profitable Technology: The Case of Seasonal Migration in Bangladesh'. Econometrica, 82(5): 1-43. https://doi.org/10.3982/ECTA10489 
Bryan, G., A.M. Mobarak, K. Naguib, M. Reimão, and A. Shenoy (2019). 'No Lean Season 2017-2019 Evaluation’. AEA Randomized Controlled Trial. Registry ID AEARCTR-0002685.

Clemens, M., and H. Postel (2017). 'Temporary Work Visas as US-Haiti Development Cooperation: A Preliminary Impact Evaluation'. IZA Journal of Labor and Development, 6(4). https://doi.org/10.1186/ s40175-016-0070-x

Deaton, A. (2005). 'Measuring Poverty in a Growing World (or Measuring Growth in a Poor World)'. Review of Economics and Statistics, 87(1): 1-19. https://doi.org/10.1162/0034653053327612

Dingel, J., and B. Neiman (2020). 'How Many Jobs Can be Done at Home?' COVID Economics: Vetted and Real-Time Papers, 1: 16-24.

Egger, D., E. Miguel, S.S. Warren, A. Shenoy, E. Collins, D. Karlan, D. Parkerson, A.M. Mobarak, G. Fink, C. Udry, M. Walker, J. Haushofer, M. Larreboure, S. Athey, P. Lopez-Pena, S. Benhachmi, M. Humphreys, L. Lowe, N.F. Meriggi, A. Wabwire, C.A. Davis, U.J. Pape, T. Graff, M. Voors, C. Nekesa, and C. Vernot (2020). 'Falling Living Standards During the COVID-19 Crisis: Quantitative Evidence from Nine Developing Countries'. Mimeo.

Fasani, F., and J. Mazza (2020). 'Immigrant Key Workers: Their Contribution to Europe's COVID-19 Response'. IZA Policy Paper 155. Bonn: IZA.

Flaxman, S., S. Mishra, A. Gandy, H.J.T. Unwin, T.A. Mellan, H. Coupland, C. Whittaker, H. Zhu, T. Berah, J.W. Eaton, M. e. Monod, Imperial College COVID-19 Response Team, A.C. Ghani, C.A. Donnelly, S.M. Riley, M.A.C. Vollmer, N.M. Ferguson, L.C. Okell, and S. Bhatt (2020). 'Estimating the Effects of Non-Pharmaceutical Interventions on COVID-19 in Europe'. Nature. 584: 257-61. https://doi.org/10.1038/ s41586-020-2405-7

Garg, S., L. Kim, M. Whitaker, A. O’Halloran, C. Cummings, R. Holstein, M. Prill, S.J. Chai, P.D. Kirley, N.B. Alden, B. Kawasaki, K. Yousey-Hindes, L. Niccolai, E.J. Anderson, K.P. Openo, A. Weigel, M.L. Monroe, P. Ryan, J. Henderson, S. Kim, K. Como-Sabetti, R. Lynfield, D. Sosin, S. Torres, A. Muse, N.M. Bennett, L. Billing, M. Sutton, N. West, W. Schaffner, H.K. Talbot, C. Aquino, A. George, A. Budd, L. Brammer, G. Langley, A.J. Hall, and A. Fry (2020). 'Hospitalization Rates and Characteristics of Patients Hospitalized with Laboratory-Confirmed Coronavirus Disease 2019: COVID-Net, 14 States, March 1-30, 2020'. Morbidity and Mortality Weekly Report, 69: 458-64. https://doi.org/10.15585/mmwr.mm6915e3

Garrote Sanchez, D., N. Gomez Parra, C. Ozden, and B. Rijkers (2020). 'Which Jobs Are Most Vulnerable to COVID-19? What an Analysis of the European Union Reveals'. Research and Policy Brief 34. Kuala Lumpur: World Bank Malaysia Hub. https://doi.org/10.1596/33737

Gelatt, J. (2020). 'Immigrant Workers: Vital to the U.S. COVID-19 Response, Disproportionately Vulnerable'. Technical Report. Washington, DC: Migration Policy Institute.

Gottlieb, C., J. Grobovsek, and M. Poschke (2020). 'Working from Home Across Countries'. COVID Economics: Vetted and Real-Time Papers, 8: 71-91.

Government of India (GoI) (2020). 'Repatriations Under the Vande Bharat Mission Cross 5 Lakhs'. Ministry of External Affairs Press Release, 3 July.

Hale, T., S. Webster, A. Petherick, T. Phillips, and B. Kira (2020). 'Oxford COVID-19 Government Response Tracker'. Available at: www.bsg.ox.ac.uk/research/research-projects/ coronavirus-government-response-tracker.

Hsiang, S., D. Allen, S. Annan-Phan, K. Bell, I. Bolliger, T. Chong, H. Druckenmiller, L.Y. Huang, A. Hultgren, E. Krasovich, P. Lau, J. Lee, E. Rolf, J. Tseng, and T. Wu (2020). 'The Effect of Large-Scale Anti-Contagion Policies on the COVID-19 Pandemic'. Nature, 584: 262-67. https://doi.org/10.1038/s41586-020-2404-8

Imbert, C., and J. Papp (2020). 'Costs and Benefits of Rural-Urban Migration: Evidence from India'. Journal of Development Economics, 146. https://doi.org/10.1016/j.jdeveco.2020.102473

International Labour Organisation (ILO) (2020). 'ILO Warns of COVID-19 Migrant "Crisis within a Crisis"”. News Release, 24 June. 
International Monetary Fund (IMF) (2020). 'Policy Responses to COVID-19'. Available at www.imf.org/en/ Topics/imf-and-covid19/Policy-Responses-to-COVID-19 (accessed 17 April 2020).

International Organization for Migration (IOM) (2020a). 'IOM Assists Vulnerable Returning Migrants Impacted by the COVID-19 Pandemic'. Press Release, 21 July.

International Organization for Migration (IOM) (2020b). 'Mobility Restrictions on Countries' Points of Entry in Response to COVID-19'. Technical Report. Grand-Saconnex: IOM.

Janetsky, M. (2020). 'Guatemalan Deportees from US Face Coronavirus Stigma, Threats and Violence'. Voice of America News, 19 May.

Kerwin, D., M. Nicholson, D. Alulema, and R. Warren (2020). 'US Foreign-Born Essential Workers by Status and State, and the Global Pandemic'. Technical Report. New York: Center for Migration Studies.

Kraemer, M.U.G., C.-H. Yang, B. Gutierrez, C.-H. Wu, B. Klein, D.M. Pigott, L. du Plessis, N.R. Faria, R. Li, W.P. Hanage, J.S. Brownstein, M. Layan, A. Vespignani, H. Tian, C. Dye, O.G. Pybus, and S.V. Scarpino (2020). 'The Effect of Human Mobility and Control Measures on the COVID-19 Epidemic in China'. Science, 368: 493-97. https://doi.org/10.1126/science.abb4218

Lagakos, D., S. Marshall, A.M. Mobarak, C. Vernot, and M.E. Waugh (2020). 'Migration Costs and Observational Returns to Migration in the Developing World'. Journal of Monetary Economics, 113: 138-54.

Lopez-Pena, P., C.A. Davis, and A.M. Mobarak (2020). 'Prevalence and Correlates of Depression Among Rohingya Refugees and Bangladeshis Living in Cox's Bazar: A Representative, Cross-Sectional Survey'. Mimeo.

McKenzie, D., S. Stillman, and J. Gibson (2010). 'How Important Is Selection? Experimental vs. NonExperimental Measures of the Income Gains from Migration'. Journal of the European Economic Association, 8(4): 913-45. https://doi.org/10.1111/j.1542-4774.2010.tb00544.x

Mobarak, A.M., and C. Vernot (2020). 'Credit to Address Seasonal Poverty when Migration Income Is Lumpy'. AEA Randomized Controlled Trial. Registry ID AEARCTR-0005866.

Morten, M. (2019). 'Temporary Migration and Endogenous Risk Sharing in Village India'. Journal of Political Economy, 127(1): 1-46. https://doi.org/10.1086/700763

Roy, R., and V. Agarwal (2020). 'Millions of Indians Are Fleeing Cities, Raising Fears of a Coronavirus "Land Mine" in Villages'. Wall Street Journal, 27 May.

Saltiel, F. (2020). 'Who Can Work from Home in Developing Countries?' COVID Economics: Vetted and RealTime Papers, 6: 104-18.

Saydia (2020). 'Hunger Lockdown Timeline: Protests over Relief in 64 Districts in a Month'. Thotkata, 29 April.

Shrestha, M., A.M. Mobarak, and I.A. Sharif (2020). 'Migration and Remittances: The Impacts of a Government Intermediated International Migration Program'. Policy Research Working Paper 9165. Washington, DC: World Bank Group.

Tribune, The (2020). ‘ 4 Crore Migrant Workers in India; 75 Lakh Return Home so Far: Mha'. The Tribune, 23 May.

United Nations Department of Economic and Social Affairs (UNDESA) (2013). 'Cross-National Comparisons of Internal Migration: An Update on Global Patterns and Trends'. Population Division Technical Paper 2013/1. New York: UNDESA.

United Nations Department of Economic and Social Affairs (UNDESA) (2019). 'International Migrant Stock 2019'. Technical Report. New York: UNDESA.

United Nations Population Fund (UNFPA) (2016). ‘Urbanization and Migration in Bangladesh'. Technical Report. New York: UNFPA.

Valsecchi, M. (2020). 'Internal Migration and the Spread of COVID-19. COVID Economics: Vetted and Real-Time Papers', 18: 170-95. 
World Bank (2020a). 'COVID-19 Crisis Through a Migration Lens'. Migration and Development Brief 32. Washington, DC: World Bank.

World Bank (2020b). ‘World Development Indicators'. Database. Washington, DC: World Bank. 


\section{Disclosure statement}

All data collection was approved by the Yale University Institutional Review Board. The order of author names is alphabetical as all authors contributed to data collection, analysis, and writing. Naguib and Reimão were employed by Evidence Action, the implementing partner for the No Lean Season experiment, from 2016 to 2019. Mitchell's current position at Y-RISE is also funded by Evidence Action. No institution had the right to review results before publication. The remaining authors declare we have no conflicts of interest. 


\section{Appendix}

\section{A1 Data}

The analysis in this paper primarily uses four COVID-19-specific phone surveys that sample from participants in existing studies and took place in April-May 2020. These data are supplemented by nationally representative household surveys and by studies on the prevalence of and returns to migration to generate Figure 1.

Government-to-Government (G2G): The G2G sample, conducted in Bangladesh, consists of individuals who applied for a visa lottery in 2013, intermediated by the Government of Bangladesh, for a temporary work programme in the palm sector in Malaysia. The Government of Bangladesh determined via lottery (conducted independently by the Bangladesh University of Engineering and Technology) which 30,000 individuals would receive work visas of the 1.43 million who applied. This study aims to understand the impact on households of winning the work visa lottery, and more generally to estimate the returns to short-term international migration. Details of the evaluation are discussed by Shrestha et al. (2020).

In 2018 the project tracked and administered surveys to lottery applicant households, including both lottery winners and losers, in 49 subdistricts in the two largest divisions of Bangladesh-Chittagong and Dhaka - via an in-person survey. The population is representative of lottery applicant households in Dhaka and Chittagong divisions; in practice, this sample should roughly be thought of as middle-class Bangladeshis since the poorest households in the country are unlikely to be able to afford the cost of travelling abroad.

For our COVID-19-specific phone survey we attempted to contact 4,608 study participants, stratified by lottery outcome, out of which 2,937 consented to participate.

Western Terai, Nepal (NPL): NPL data comes from an existing phone panel of 1,820 rural households in the districts of Kailali and Kanchanpur, two of the poorer districts in the country. This sample was constructed in June 2019 by randomly selecting 30 wards from 17 of 20 subdistricts, and then selecting a random 90 villages from within those wards. The households surveyed come from the bottom half of the wealth distribution in these villages as estimated by a participatory wealth ranking exercise with members of the village. A substantial fraction of income for these households comes from remittances from migrants in India or elsewhere in Nepal. Initial baseline data were collected in person in July 2019, and five rounds of phone survey data were collected between August 2019 and January 2020. Details of the planned evaluation are documented by Mobarak and Vernot (2020).

Our COVID-19-specific phone survey constituted the most recent round of the ongoing panel with all 1,820 study participants, out of which 1,419 were reached and consented to participate.

No Lean Season (NLS): The NLS study consists of several rounds of data collection in northern Bangladesh from 2008 to 2019. The study is a randomized evaluation of a short-term zero-interest migration loan offered during the agricultural lean season to landless agricultural households. The first two rounds of study, from which we report estimates of the causal return to migration, included 1,900 households in 2008 and 3,600 in 2014. Full details from these studies are discussed by Bryan et al. (2014) and Akram et al. (2017), respectively.

In 2017 and 2018, the loan programme was expanded to a large scale, with 158,014 loans made in 2017 and 143,721 in 2018. For evaluation, the project surveyed a subset of 4,428 eligible households in May 2018 and 4,324 households in June 2019. The project surveyed an additional 19,396 workers at 
200 spot labour markets in nine Bangladeshi cities in September 2018, and conducted follow-up phone surveys with 8,490 of them in April 2019. Details of the evaluation at scale are discussed by Bryan et al. (2019).

For our COVID-19-specific phone survey we attempted to contact 388 study participants from the 2019 round of evaluation, stratified by prior migration experience, out of which 294 consented to participate.

Cox's Bazar Panel Survey (CBPS): The CBPS is a longitudinal study tracking over 5,000 households representative of both refugee and host populations in Cox's Bazar district of Bangladesh, which is currently home to over 860,000 stateless Rohingya refugees from Myanmar. The study targets adults aged 15 or above and monitors living conditions in refugee camps and host communities, with baseline data collected between April and July 2019. Baseline data collection involved interviews covering a wide range of topics, including detailed questions on labour market outcomes, trauma, and mental health. The data generated by this project were first reported by Lopez-Pena et al. (2020).

For our COVID-19-specific phone survey we attempted to contact 1,255 study participants, out of which 899 consented to participate. Of these, 704 respondents were the household member who had also responded to the baseline survey, while in the remaining 195 households the respondent was a different member of the same household.

National Survey Data: The national migration rates in Panel A of Figure 1 are calculated using nationally representative datasets. Data for Nepal come from the 2010-11 round of the Nepal Living Standards Survey (NLSS). Ugandan data come from the 2009 and 2011 waves of the Uganda National Panel Survey (UNPS). Migration rates in the USA are computed from the 1996, 2001, 2004, and 2008 rounds of the Survey of Income and Program Participation (SIPP). 


\section{A2 Mobility restrictions in Bangladesh and Nepal}

Table A1: COVID-19 government mobility policies in Bangladesh and Nepal

\begin{tabular}{|c|c|c|}
\hline & Bangladesh as of 16 May & Nepal as of 28 May \\
\hline School closing & All schools closed & All schools closed \\
\hline Workplace closing & Closing/work from home, some sectors & Closing/work from home, some sectors \\
\hline Cancel public events & Required cancelling & Required cancelling \\
\hline Restrictions on gatherings & $\begin{array}{l}\text { Restrictions on gatherings } \\
\text { of } 10 \text { people or fewer }\end{array}$ & $\begin{array}{l}\text { Restrictions on gatherings } \\
\text { of } 10 \text { people or fewer }\end{array}$ \\
\hline Close public transport & $\begin{array}{l}\text { Require closing (or prohibit } \\
\text { most citizens from using it) }\end{array}$ & $\begin{array}{l}\text { Require closing (or prohibit } \\
\text { most citizens from using it) }\end{array}$ \\
\hline Stay home requirements & $\begin{array}{l}\text { Require not leaving house with } \\
\text { exceptions for daily exercise, grocery } \\
\text { shopping, and 'essential' trips }\end{array}$ & $\begin{array}{l}\text { Require not leaving house with } \\
\text { exceptions for daily exercise, grocery } \\
\text { shopping, and 'essential' trips }\end{array}$ \\
\hline Domestic travel restrictions & Internal movement restrictions in place & Internal movement restrictions in place \\
\hline Foreign travel restrictions & Ban arrivals from some regions & Ban on all regions or total border closure \\
\hline
\end{tabular}

Source: authors' construction, based on on Hale et al. (2020). 